\title{
PENGARUH DUKUNGAN ORGANISASI DAN KEJELASAN TUGAS SERTA LINGKUNGAN KERJA TERHADAP MOTIVASI DAN PROFESIONAL KERJA PERAWAT DI RSUD JARAGA SASAMEH BUNTOK
}

\author{
Yudith Dwi Angela \\ Sekolah Tinggi Ilmu Ekonomi Pancasetia Banjarmasin \\ J1. Ahmad Yani Km. 5.5 Banjarmasin \\ yudithdwiangelahb@gmail.com
}

\begin{abstract}
Abstrak: Penelitian ini bertujuan untuk menganalisis pengaruh Dukungan Organisasi, Kejelasan Tugas, Lingkungan Kerja terhadap Motivasi Kerja Perawat dan Profesional Kerja juga untuk menganalisa pengaruh Motivasi Kerja terhadap Profesional Kerja Perawat di RSUD Jaraga Sasameh Buntok. Model path analysis digunakan untuk menganalisis pola hubungan antar variabel dengan tujuan untuk mengetahui pengaruh langsung dan pengaruh tidak langsung seperangkat variabel bebas (eksogen) terhadap variabel terikat (endogen). Model path analysis yang dibicarakan adalah pola hubungan sebab akibat atau "a set of hypothesized causal asymmetric relation among the variables".

Kata Kunci : Dukungan Organisasi, Kejelasan Tugas; Lingkungan Kerja; Motivasi dan Profesional Kerja.

Abstract: This study aims to analyze the influence of organizational support, clarity of tasks, work environment on employee motivation and work professionalism as well as to analyze the effect of work motivation on professional work employees of RSUD Jaraga Sasameh Buntok. The path analysis model is used to analyze the pattern of relationships between variables in order to determine the direct and indirect effect of a set of independent (exogenous) variables on the dependent variable (endogenous). The path analysis model discussed is a pattern of causal relationships or "a set of hypothesized causal asymmetric relations among the variables".
\end{abstract}

Keywords: Organizational Support, Clarity of Tasks; Work environment; Motivation and professional. 


\section{PENDAHULUAN}

Semakin kompetitifnya persaingan dalam industri jasa dewasa ini, mengharuskan organisasi memiliki keunggulan yang sifatnya berkesinambungan (sustainable advantage), tujuannya agar mampu bersaing dengan organisasi lainnya.Satu di antara keunggulan bersaing yang harus dimiliki oleh organisasi jasa adalah memiliki pegawai yang unggul sesuai dengan kebutuhan strategi dan menghasilkan kinerja yang baik sesuai dengan tujuan organisasi.

Universitas Trunajaya Bontang adalah univeristas yang dituntut untuk terus menghasilkan jasa yang optimal bagi pengguna jasanya. Prestasi kerja pegawai diwujudkan dalam kemampuannya memberikan pelayanan yang unggul yaitu suatu sikap atau cara pegawai dalam melayani pelanggan secara memuaskan. Prestasi kerja pegawai melalui kualitas layanan yang diberikan merupakan suatu keharusan dan strategi. Apabila kualitas pelayanan yang diberikan melalui prestasi kerja pegawainya mampu memuaskan pengguna jasa, maka pengguna jasa akan merasa puas yang loyal dan tetap menggunakan jasa organisasi, ini akan mendorong kinerja organisasi. Hal ini berarti bahwa setiap organisasi perlu berupaya memperbaiki prestasi pegawainya untuk memberikan kualitas pelayanan terbaik bagi pelanggannya.Pelayanan yang baik berarti mampu memberikan kinerja seperti yang diharapkan oleh pengguna jasa.

Sebaliknya, apabila kinerja pegawai melalui pelayanan yang diberikan tidak baik atau tidak memuaskan yang berarti bahwa kinerja yang diberikan masih belum seperti yang diharapkan, hal ini akan berdampak pada ketidak puasan konsumen, perpindahan konsumen kepada penyedia jasa yang lain, cerita dari mulut ke mulut tentang hal yang negatif sehingga menyebabkan citra yang kurang baik bagi organisasi di mata masyarakat, dan pada giliranya nanti akan mengakibatkan kerugian bagi organisasi.

Cara untuk meningkatkan kualitas pelayanan adalah dengan memahami dan memperlakukan pegawai lini depan (frontliners) dengan tepat. Pegawai yang memiliki kontak dengan pelanggan adalah sumber kunci bagi organisasi jasa, karena pada saat terjadi interaksi antara pelanggan dengan pegawai lini depan maka kinerja organisasi sepenuhnya pada saat itu ditentukan oleh prestasi pegawai tersebut. Prestasi pegawai pada saat itu akan menentukan apakah konsumen akan mengkonsumsi lagi jasa tersebut pada kesempatan berikutnya. Untuk memotivasi pegawai lini depan agar dapat berinteraksi dengan pelanggan dengan baik diperlukan pemimpin yang dapat dengan baik memotivasi mereka.

Berbicara tentang pelayanan tidak terlepas dari pengelolaan sumber daya manusia sebagai penghantarnya. Organisasi yang dapat bertahan dan menang dalam persaingan adalah organisasi yang mampu mengelola sumber daya (resources) yang dimiliki. Sumber daya manusia adalah merupakan salah satu faktor kunci untuk membangun suatu keunggulan kompetitif yang berkesinambungan. Hal ini menunjukan bahwa sumber daya manusia melalui kemampuannya berperilaku dalam memberikan pelayanan tidak boleh diabaikan.

Efektifitas pengelolaan organisasi di bidang jasa ditunjukkan oleh kemampuan memberikan pelayanan memuaskan. Manajer selaku pimpinan dari organisasi haruslah mempelajari dan memahami perilaku bawahannya dan mendorongnya demi pencapaian tujuan organisasi secara efektif. Untuk itu, pimpinan, yang mengemban tugas untuk mencapai tujuan organisasi harus melakukan evaluasi prestasi bawahan untuk memastikan apakah mereka telah melaksanakan tugas pelayanan secara baik atau belum.

Prestasi kerja adalah pencapaian atas tujuan organisasi yang dapat berbentuk 
output kuantitatif maupun kualitatif, kreatifitas, fleksibilitas, dapat diandalkan, atau hal-hal lain yang dinginkan oleh organisasi Brahmasari, (2009). Untuk mendorong prestasi kerja pegawai agar memberikan pelayanan dengan baik hal yang bisa dilakukan organisasi di antaranya adalah dengan berupaya menciptakan kepuasan kerja pegawai. Kepuasan kerja dapat tercipta jika variabel yang mempengaruhinya antara lain lingkungan kerja, kompensasi dan komitmen organisasi dapat diakomodasi dan diterima dengan baik di dalam suatu organisasi. Kinerja organisasi tergantung pada prestasi individu yang artinya bahwa perilaku anggota organisasi baik secara individu maupun kelompok memberikan kekuatan atas prestasi organisasi sebab motivasinya akan mempengaruhi kinerja organisasi.

Kepentingan para pimpinan terhadap kepuasan kerja cenderung terpusat efeknya pada prestasi pegawai Robbin (2010). Untuk itu banyak faktor yang perlu diperhatikan dalam menganalisis kepuasan kerja pegawai. Secara teori faktor-faktor yang mempengaruhi kepuasan kerja sangat banyak jumlahnya, seperti gaya kepemimpinan, produktivitas kerja, perilaku, locus of control, pemenuhan harapan penggajian dan efektivitas kerja Rivai (2011). Dengan demikian untuk memuaskan pegawai diperlukan pengetahuan tentang variabel-variabel yang menciptakan kepuasan kerja dan berusaha memenuhinya, sehingga diharapkan akan berdampak pada keinginan pegawai untuk memperbaiki prestasi kerjanya yaitu memberikan pelayanan lebih baik dari waktu ke waktu.

\footnotetext{
Kepuasan kerja merujuk pada sikap umum seorang individu terhadap pekerjaannya (Robbin, 2010). Seseorang dengan tingkat kepuasan kerja tinggi menunjukkan sikap yang positif terhadap kerja itu; seseorang yang tidak puas dengan pekerjaannya menunjukkan sikap negatif pada pekerjaannya itu. Pegawai yang tidak puas dapat menyatakannya dengan berbagai cara seperti meninggalkan organisasi, bersuara untuk memperbaiki kondisi,
}

menunggu membaiknya kondisi, dan membiarkan kondisi memburuk termasuk mengurangi upaya dan meningkatnya tingkat kekeliruan karena pegawai mengabaikan tanggung jawabnya Robbin, (2010). Apabila kondisi ini sampai terjadi, maka akan menyebabkan gangguan dalam upaya menghantarkan layanan yang memuaskan. Demikian halnya, apabila pegawai mampu menghasilkan prestasi kerja yang diharapkan, maka akan mendorong kepuasan kerja pegawai.

Di antara hal pembentuk kinerja adalah lingkungan organisasi atau lingkungan kerja. Lingkungan kerja sangat berkaitan erat dengan tinggi rendahnya kepuasaan pegawai, apabila lingkungan kerja baik maka hal tersebut dapat memberikan pengaruh yang positif terhadap kinerja pegawai, begitu pula sebaiknya. Lingkungan kerja adalah keseluruhan alat perkakas dan bahan yang dihadapi, lingkungan sekitarnya dimana seseorang bekerja, metode kerjanya, serta pengaturan kerjanya baik sebagai perseorangan maupun sebagai kelompok. Organisasi dapat berkembang merupakan keinginan setiap individu yang berada dalam organisasi tersebut, sehingga diharapkan dengan perkembangan tersebut organisasi mampu bersaing dalam mengikuti perkembangan zaman. Karena itu, tujuan yang diharapkan oleh organisasi dapat tercapai dengan baik.

Kemajuan organisasi di pengaruhi oleh faktor-faktor lingkungan yang bersifat intenal dan eksternal. Sejauh mana tujuan organisasi telah tercapai dapat dilihat dari seberapa besar organisasi memenuhi tuntutan lingkungannya, kondisi kerja adalah keadaan dimana tempat kerja yang baik meliputi fisik atau non fisik yang dapat memberikan kesan menyenangkan, aman, tentram dan lain sebagainya. Apabila kondisi kerja baik maka hal tersebut dapat memacu timbulnya rasa puas dalam diri pegawai yang pada akhirnya dapat memberikan pengaruh positif terhadap kinerja pegawai, begitu sebaliknya, apabila kondisi kerja buruk maka pegawai tidak akan mempunyai kepuasan dalam bekerja. 
Suatu kondisi lingkungan kerja dikatakan baik atau sesuai apabila manusia dapat melaksanakan kegiatan secara optimal, sehat, aman, dan nyaman.

Kesesuaian lingkungan kerja dapat dilihat akibatnya dalam jangka waktu yang lama lebih jauh lagi lingkungan-lingkungan kerja yang kurang baik dapat menutut tenaga kerja dan waktu yang lebih banyak dan tidak mendukung diperolehnya rancangan sistem kerja yang efisien. Jenis lingkungan kerja terbagi menjadi dua yaitu lingkungan kerja fisik merupakan suatu keadaan berbentuk fisik yang terdapat disekitar tempat kerja yang dapat mempengaruhi pegawai baik secara langsung maupun tidak langsung yang kedua lingkungan kerja Non fisik merupakan semua keadaan terjadi yang berkaitan dengan hubungan kerja, baik hubungan dengan atasan maupun dengan hubungan sesama rekan kerja, ataupun dengan bawahan.

Selain dipengaruhi oleh lingkungan kerja, prestasi dan kepuasan pegawai juga dipengaruhi oleh kompensasi. Kompensasi adalah balas jasa yang diberikan oleh organisasi akibat kontribusi pegawai terhadap organisasi. Kompensasi merupakan salah satu alasan mengapa seseorang memilih untuk bekerja di suatu organisasi tertentu. Semakin organisasi memperhatikan kompensasi pegawai, maka pegawai akan semakin terdorong bekerja lebih baik. Seperti yang dikemukakan oleh Hariandja (2009), bahwa tujuan utama pemberian kompensasi adalah untuk menarik pegawai yang yang berkualitas, mempertahankan pegawai, memotivasi pegawai, membangun komitmen pegawai.

Kompensasi juga merupakan pendorong kepuasan pegawai, selain merupakan faktor pendorong prestasi kerja. Jika kompensasi pegawai diperhatikan maka akan menghasilkan kepuasan pegawai, baik dalam bentuk kompensasi finansial maupun non finansial. Seperti diungkapkapkan oleh Hariandja (2009), bahwa salah satu faktor yang mempengaruhi kepuasan kerja adalah
kompensasi.Agar diperoleh hasil kerja yang optimal, pegawai hendaknya memiliki komitmen organisasi. Komitmen organisasional adalah tingkat seseorang mengenal dengan kuat dan merasa menjadi bagian organisasi. Porter dalam Kuntjoro (2010), menyatakan bahwa komitmen organisasional adalah kekuatan yang bersifat relatif dari individu dalam mengidentifikasikan keterlibatan dirinya ke dalam bagian organisasi.

$\begin{array}{ccr}\text { Pegawai yang } & \text { mempunyai } \\ \text { komitmen organisasi tinggi akan }\end{array}$ mencirikan individu yang mempunyai daya saing tinggi untuk dapat memberikan kemampuan maksimal untuk pencapaian tujuan organisasi. Komitmen dipandang sebagai suatu orientasi nilai terhadap organisasai yang menunjukan individu sangat memikirkan dan mengutamakan pekerjaan dan organisasinya.

Kepuasan kerja mencerminkan sikap dan bukan perilaku. Kepuasan kerja merupakan variabel yang menunjukkan hubungan dengan faktor prestasi dan merupakan preferensi nilai yang dipegang banyak peneliti perilaku organisasi, pegawai yang mempunyai kepuasan kerja seharusnya mampu memiliki prestasi kerja. Prestasi kerja merupakan perilaku kerja yang berpengaruh langsung terhadap kepuasan kerja pegawai. Berdasarkan pendapat tersebut maka dapat disimpulkan bahwa ada hubungan yang signifikan antara prestasi dan kepuasan kerja. Prestasi kerja merupakan variabel yang dipengaruhi oleh variabel kepuasan kerja pegawai pada Universitas Trunajaya Bontang.

\section{Kajian Pustaka}

\section{Dukungan Organisasi dan Motivasi Kerja}

Kreteria utama yang dirasakan pegawai mengenai lingkungan kerja adalah bagaimana kondisi konkret yang dirasakan atau dihayati oleh para pegawai. Buktibukti menyatakan bahwa setiap manusia itu baik secara individual maupun kolektif memberikan reaksi dengan sensitivitas/kepekaan yang lebih tinggi 
terhadap perubahan iklim psikologis daripada kondisi fisik. Khususnya jika dibandingkan dengan reaksi terhadap kondisi fisik lingkungan kerja misalnya terhadap kenaikan suhu, ventilasi yang kurang baik, udara yang lembab dikantor, kurang cahaya dan lain-lain yang merupakan faktor mempengaruhi kepuasan kerja Muttaqiyathun, (2011).

Berdasarkan penjelasan tersebut maka dapat diambil kesimpulan bahwa kepuasan pegawai merupakan variabel yang dipengaruhi oleh variabel lingkungan kerja pegawai pada Universitas Trunajaya Bontang.

\section{Kejelasan Tugas dan Motivasi Kerja}

Salah satu aspek yang dapat membentuk kepuasan kerja pegawai adalah aspek kompensasi.Oleh karena itu seringkali jalan yang ditempuh departemen personalia untuk meningkatkan kepuasan kerja adalah melalui peningkatan bidang kompensasi Handoko (2009).

Menurut Wiryawan (2009), menyatakan bahwa kompensasi merupakan pengaruh dari dalam internal organisasi yang dapat mempengaruhi kepuasan kerja dimana kepuasan kerja termasuk di dalam perilaku kerja pegawai.

Menurut Hatta (2011), menyatakan bahwa sistem imbalan atau kompensasi yang baik adalah sistem yang menjamin kepuasan para anggota organisasi yang pada gilirannya memungkinkan organisasi memperoleh, memelihara dan mempekerjakan sejumlah orang yang dengan berbagai sikap dan perilaku positif bekerja secara produktif bagi kepentingan organisasi.

Berdasarkan dari beberapa pendapat tersebut di atas maka dapat disimpulkan bahwa ada hubungan yang signifikan antara kompensasi dan kepuasan kerja adalah dengan meningkatkan kompensasi yang berupa insentif dalam bentuk tunjangan kesehatan, fasilitas pinjaman perumahan dan fasilitas pendidikan akan mampu mempengaruhi kepuasan kerja pegawai.

\section{Lingkungan Kerja dan Motivasi Kerja}

Setiap anggota organisasi memiliki kesempatan yang sama, misalnya untuk promosi maka dasar yang digunakan untuk promosi adalah kemampuan, keterampilan, minat, motivasi, kinerja, serta meraih kepuasan kerja tanpa adanya diskriminasi. Dengan demikian kepuasan kerja mempunyai hubungan yang penting dengan komitmen organisasi, kepuasan kerja merupakan salah satu aspek proses terjadinya komitmen organisasi. Dalam literatur psikologi organisasi, komitmen organisasi dan kepuasan biasanya berkembang secara independent sampai batas tertentu.Menurut Meyer (2009:89) mengatakan bahwa komitmen merupakan salah satu komponen dari kepuasan yang penting, Meyer berkeyakinan bahwa komitmen dianggap sebagai salah satu bagian penting bagi kepuasan.

Berdasarkan penjesalan tersebut maka dapat diambil kesimpulan bahwa komitmen organisasi merupakan variabel yang dipengaruhi oleh variabel lingkungan kerja pegawai secara positif dan signifikan pada RSUD Jaraga Sasameh Buntok.

\section{Dukungan Organisasi dan Profesional Kerja}

Sumber daya manusia berperan dalam mengolah dan memanfaatkan sumber daya dan material sehingga menjadi produk. Oleh karena itu untuk meningkatkan prestasi, perlu diperhatikan agar sumber daya manusia dapat bekerja secara efisien dan menampilkan kinerja yang bisa memberi sumbangan terhadap produktivitas merupakan masalah mendasar untuk pencapaian prestasi kerja, Yunanda (2012).

Lingkungan kerja merupakan segala sesuatu yang ada di sekitar para pekerja dan yang dapat mempengaruhi dirinya dalam menjalankan tugas yang dia emban atau yang menjadi tanggung jawabnya. Untuk meningkatkan produktivitasnya maka lingkungan kerja sangat mempengaruhi prestasi kerja karena lingkungan kerja yang baik akan menciptakan kemudahan 
pelaksanaan tugas. Lingkungan kerja ini sendiri terdiri dari lingkungan kerja fisik dan non fisik yang melekat dengan pegawai sehingga tidak dapat dipisahkan dari usaha pengembangan prestasi kerja pegawai, Yunanda (2012).

Berdasarkan penjelasan tersebut maka dapat diambil kesimpulan bahwa prestasi kerja merupakan variabel yang dipengaruhi oleh variabel lingkungan kerja pegawai pada RSUD Jaraga Sasameh Buntok

\section{Kejelasan Tugas dan Profesional Kerja}

Kompensasi merupakan kontra prestasi terhadap penggunaan tenaga atau jasa yang diberikan oleh tenaga kerja. Kompensasi merupakan paket yang ditawarkan organisasi kepada pekerja sebagai imbalan atas penggunaan tenaga kerjanya. Kompensasi didefinisikan sebagai apa yang diterima pekerja sebagai tukaran atas kontribusinya kepada organisasi Werther dan Davis, (2010). Di dalam kompensasi terdapat system insentif yang menghubungkan kompensasi dengan pencapaian prestasi kerja, Wibowo (2010).

Menurut Wiryawan (2009), menyatakan bahwa kompensasi merupakan lingkungan internal organisasi yang dapat berpengaruh langsung terhadap prestasi kerja. Berdasarkan dari beberapa pendapat tersebut di atas maka dapat disimpulkan bahwa ada hubungan yang signifikan antara kompensasi dan prestasi kerja adalah suatu sistem insentif yang diberikan organisasi kepada pegawai sehingga mampu meningkatkan prestasi kerjanya.

\section{Lingkungan Kerja dan Profesional Kerja}

Komitmen organisasi merupakan kepercayaan kepada nilai-nilai organisasi, kesediaan untuk berusaha sebaik mungkin demi kepentingan organisasi dan keinginan untuk tetap menjadi anggota organisasi yang bersangkutan yang dinyatakan oleh seorang pegawai terhadap organisasinya. Selanjutnya Steers menyatakan bahwa komitmen organisasional merupakan kondisi dimana pegawai sangat tertarik terhadap tujuan, nilai-nilai dan sasaran organisasinya. Komitmen terhadap organisasi artinya lebih dari sekedar keanggotaan formal, karena meliputi sikap menyukai organisasi dan kesediaan untuk mengusahakan tingkat upaya yang tinggi bagi kepentingan organisasi demi pencapaian tujuan. Komitmen organisasi mempunyai peranan penting dalam pembentukan karakter organisasi, melalui komitmen organisasi pegawai akan mempunyai daya saing yang diukur melalui kinerja yang telah dicapai.

Menurut Robbins (2009), menemukan pengaruh komitmen organisasi terhadap prestasi kerja, komitmen dipandang sebagai suatu orientasi nilai terhadap organisasi yang menunjukan individu sangat memikirkan dan mengutamakan pekerjaan dan organisasinya. Individu akan berusaha memberikan segala usaha yang dimilikinya dalam rangka membantu organisasi mencapai tujuannya.

Berdasarkan penjelasan tersebut maka dapat diambil kesimpulan bahwa prestasi kerja merupakan variabel yang dipengaruhi oleh variabel komitmen organisasi pada RSUD Jaraga Sasameh Buntok.

\section{Motivasi Kerja dan Profesional Kerja}

Kepuasan kerja mencerminkan sikap dan bukan perilaku. Kepuasan kerja merupakan variabel yang menunjukkan hubungan dengan faktor prestasi dan merupakan preferensi nilai yang dipegang banyak peneliti perilaku organisasi, Wibowo (2010).

Menurut Wiryawan
menyatakan bahwa prestasi
merupakan perja
berpengaruh langsung terhadap kepuasan
kerja pegawai. Berdasarkan pendapat
tersebut maka dapat disimpulkan bahwa ada
hubungan yang signifikan antara prestasi
dan kepuasan kerja. Prestasi kerja
merupakan variabel yang dipengaruhi oleh


variabel kepuasan kerja pegawai pada RSUD Jaraga Sasameh Buntok.

Gambar tersebut menunjukkan bahwa profesional kerja dan motivasi pegawai merupakan variabel yang dipengaruhi oleh variabel Dukungan Organisasi, Kejelasan Tugas dan Lingkungan Kerja perawat di RSUD Jaraga Sasameh Buntok. ‘

\section{METODE}

\section{Definisi operasional}

Variabel-variabel yang digunakan dalam penelitian ini terdiri dari dua kelompok variabel yaitu : variabel endogen atau variabel yang dipengaruhi yang dalam peneltian ini ditunjukkan oleh prestasi dan Motivasi Kerja Pegawai (Y) dan penggunaan variabel-variabel eksogen atau variabel yang mempengaruhi (X) yaitu Dukungan Organisasi, Kejelasan dan lingkungan kerja. Sesuai dengan identifikasi varibel penelitian, maka definisi operasional dari masing-masing variabel adalah :

Profesional Kerja adalah merupakan rata-rata hasil penilaian dari pimpinan/atasan langsung terhadap prestasi kerja masing-masing perawat di RSUD Jaraga Sasameh Buntok. Batasan mengenai indikator yang mempengaruhi profesional kerja yaitu :

- Kualitas kerja individu

- Pengetahuan tentang pekerjaan

- Kreativitas

- Tingkat inisiatif dalam menyelesaikan pekerjaan

- Tingkat kerjasama pegawai dalam menyelesaikan pekerjaan

- Hubungan kerja antar pegawai atau dengan atasan

- Disiplin kerja

Motivasi kerja adalah tingkat perasaan dan sikap pegawai terhadap segala sesuatu yang berkaitan dengan pekerjaannya pada RSUD Jaraga Sasameh Buntok. Batasan mengenai indikator yang mempengaruhi Motivasi Kerja yaitu :

- Kepuasan dengan gaji

- Kepuasan dengan promosi

- Kepuasan dengan rekan sekerja

- Kepuasan dengan atasan

- Kepuasan dengan pekerjaan itu sendiri.

Kejelasan Tugas adalah balas jasa yang diberikan oleh organisasi terhadap pegawai dalam bentuk finansial dan non finansial pada RSUD Jaraga Sasameh Buntok indikator sebagai berikut :

- Gaji sesuai dengan beban kerja

- Insentif

- Hubungan sesama pegawai

- Waktu istirahat

- Fasilitas kerja

Dukungan Organisasi adalah suatu keadaan dimana seseorang pegawai memihak organisasi tertentu serta tujuantujuan dan keinginannya untuk mempertahankan keanggotaan dalam organisasi tersebut. Indikator yang digunakan adalah sebagai berikut :

- Kebanggaan terhadap organisasi Kepedulian terhadap organisasi

- Hasrat yang kuat untuk bekerja pada organisasi

- Kepercayaan yang kuat terhadap nilainilai organisasi

- Kemauan yang besar untuk berusaha bagi organisasi

Lingkungan kerja adalah segala sesuatu yang ada disekitar pekerja yang dapat mempengaruhi dalam berkerja. Indikator yang mempengaruhi lingkungan kerja pegawai yaitu : 
- Penerangan

- Suhu udara

- Suara bising

- Ruang gerak

- Keamanan kerja

\section{Metode Pengumpulan data}

Data yang digunakan dalam penelitian ini adalah data primer dan data sekunder. Data sekunder diambil dari laporan pada RSUD Jaraga Sasameh Buntok. Data primer yaitu data yang berhubungan dengan indikator yang didapat dari responden yang mengisi kuisioner. Data dalam penelitian ini dikumpulkan dengan beberapa metode, yaitu sebagai berikut :

Penelitian kepustakaan (library research) yaitu pencarian bahan-bahan dan toeri-teori dengan mempelajari, meneliti, mengkaji serta menelaah literatur-literatur yang berhubungan dengan masalah yang akan diteliti.

Observasi, yaitu pengumpulan data melalui pengamatan langsung pada objek yang diteliti.

Kuisioner, yaitu pengumpulan data dengan memberikan daftar pertanyaan kepada responden yang bersifat tertutup dengan beberapa alternatif pilihan jawaban.

Wawancara, yaitu cara pengumpulan data dengan berpedoman pada daftar pertanyaan sebelumnya. Cara ini berguna pula untuk mendapatkan masukan-masukan yang kiranya belum tercakup didalam pertanyaan kuisioner.

\section{Uji validitas dan reliabilitas}

Uji validitas berfungsi untuk menunjukkan tingkat kesahihan suatu instrumen. Instrumen yang sahih memiliki validitas tinggi. Instrumen dikatakan sahih apabila mampu mengukur apa yang diinginkan, mampu mengungkapkan data dari variabel yang diteliti, Sugiyono (2010). Nilai korelasi (R) dibandingkan dengan 0,3, jika korelasi (R) lebih besar dari 0,3 maka pertanyaan yang dibuat dikategorikan valid.

Uji reliabilitas menunjukkan sejauh mana suatu instrument dapat memberikan hasil pengukuran yang konsisten apabila pengukuran diulang dua kali atau lebih, Sugiyono (2010). Kriteria uji reliabilitas instrumen menggunakan batas 0,6, jika Cronbach Alpha lebih besar dari 0,6 maka pertanyaan dinyatakan reliabel.

\section{Analisis jalur (path analysis)}

Analisis jalur adalah suatu teknik pengembangan dari regresi linier ganda. Teknik ini digunakan untuk menguji besarnya sumbangan (kontribusi) yang ditunjukkan oleh koefisien jalur pada setiap diagram jalur dari hubungan kausal antar variabel $X_{1}, X_{2}$ dan $X_{3}$ terhadap $Y_{1}$ serta dampaknya terhadap $\mathrm{Y}_{2}$.

Analisis jalur ialah suatu teknik untuk menganalisis hubungan sebab akibat yang tejadi pada regresi berganda jika variabel bebasnya mempengaruhi variabel tergantung tidak hanya secara langsung tetapi juga secara tidak langsung.

Data yang telah dikumpulkan diberikan nilai-nilai atau skor dengan menggunakan skala Likert Sugiyono (2010), dengan perincian sebagai berikut :

Sangat setuju / selalu / sangat positif diberi skor 5 .

Setuju /sering / positif diberi skor 4 .

Ragu-ragu / kadang-kadang / netral diberi skor 3.

Tidak setuju / hampir tidak pernah / negatif diberi skor 2 .

Sangat tidak setuju / tidak pernah / diberi skor 1 .

Model path analysis digunakan untuk menganalisis pola hubungan antar variabel dengan tujuan untuk mengetahui pengaruh langsung dan pengaruh tidak langsung seperangkat variabel bebas 
(eksogen) terhadap variabel terikat (endogen).

Model path analysis yang dibicarakan adalah pola hubungan sebab akibat atau "a set of hypothesized causal asymmetric relation among the variables". Akdon, (2010).

Teknik analisis jalur dalam penelitian ini digunakan untuk menguji besarnya sumbangan yang ditunjukkan oleh koefisien jalur pada setiap diagram jalur dari hubungan masing-masing struktur yang terdiri dari :

Sub struktur 1 : melihat pengaruh langsung variabel Dukungan Organisasi, Kejelasan Tugas dan lingkungan kerja, terhadap Motivasi Kerja dengan persamaan sebagai berikut :

$\mathrm{Y}_{1}=\mathrm{PYX}_{1} \mathrm{X}_{1}+\mathrm{PYX}_{2} \mathrm{X}_{2}+\mathrm{PYX}_{3} \mathrm{X}_{3}+\mathrm{E}$.

Sub struktur 2 : melihat pengaruh langsung variabel Dukungan Organisasi, Kejelasan Tugas lingkungan kerja dan Motivasi terhadap profesional kerja dengan persamaan sebagai berikut :

\section{$\mathrm{Y}_{2}=\mathrm{PY}_{2} \mathrm{X}_{1} \mathrm{X}_{1}+\mathrm{PY}_{2} \mathrm{X}_{2} \mathrm{X}_{2}+$ $\mathrm{PY}_{2} \mathrm{X}_{3} \mathrm{X}_{3}+\mathrm{PY}_{2} \mathrm{Y}_{1} \mathrm{Y}_{2}+\mathrm{E}$.}

Analisis jalur (path analysis) dalam sub struktur pertama dan kedua dalam penelitian ini penyelesaian model dilakukan dengan bantuan Program SPSS for Windows Release 19.0.

Selanjutnya menentukan koefesien Determinasi $\left(\mathrm{R}_{2}\right)$ dan Adjusted R Square, yaitu untuk mengetahui seberapa besar kontribusi seluruh variabel bebas secara bersama-sama terhadap variable tidak bebasnya dengan nilai koefesien determinasi ganda $\left(\mathrm{R}_{2}\right)$ dan untuk melihat seberapa model yang digunakan dapat mempunyai korelasi (hubungan) dengan Adjusted R Squre.

Priyatno (2009), "Koefisien ini digunakan untuk menunjukkan seberapa besar hubungan yang terjadi antara variabel independen $\left(\mathrm{X}_{1}, \mathrm{X}=, \ldots \mathrm{Xn}\right)$ secara serentak terhadap variabel dependen (Y)". Nilai R dapat dicari dengan rumus sebagai berikut :

$\mathbf{b}_{1} \sum \mathbf{X}_{1} \mathbf{Y}+\mathbf{b}_{2} \sum \mathbf{X}_{2} \mathbf{Y} \mathbf{R}_{\mathbf{y}}=\sqrt{ } \sum \mathbf{Y}_{2}$

(Sumber : Sugiyono, 2010:286)

Untuk melihat tingkat kekuatan hubungan antara variabel $\mathrm{X}$ dengan $\mathrm{Y}$, menggunakan tabel 3.1 berikut :

Tabel 1. Interval Koefisien dan Tingkat Hubungan

\begin{tabular}{ll}
\hline $\begin{array}{l}\text { Interval } \\
\text { Koefisien }\end{array}$ & Tingkat Hubungan \\
\hline $0,00-0,199$ & Sangat \\
$0,20-0,399$ & Rendah \\
$0,40-0,599$ & Rendah \\
$0,60-0,799$ & Sedang \\
$0,80-1,000$ & Kuat \\
& Sangat Kuat \\
\hline
\end{tabular}

Sumber : Sugiyono (2010)

Priyatno (2009), “Analisis determinasi dalam regresi berganda digunakan untuk mengetahui persentase sumbangan pengaruh variabel independen $\left(\mathrm{X}_{1}, \mathrm{X}_{2}, \ldots \mathrm{X}_{\mathrm{n}}\right)$ secara serentak terhadap variabel dependen (Y)". Semakin besar nilai $\mathrm{R}_{2}$, maka semakin besar pengaruh antara variabel bebas terhadap variabel terikat.

Nilai $R_{2}$ dapat dicari dengan rumus sebagai berikut, Sunyoto (2010).

$R_{2}=b_{1} \sum X_{1} Y+b_{2} \sum X_{2} Y \sum Y_{2}$

Apabila koefisien determinasi $\left(\mathrm{R}_{2}\right)$ mendekati angka satu (1) berarti terdapat hubungan yang kuat Djarwanto dan Pangestu, (2010).

\section{Pengujian Hipotesis}

Pembukitian hipotesis menggunakan uji statistik, yaitu alat statistik uji ini untuk melihat hubungan antara variabel tidak bebas yang dapat dijelaskan oleh variabel bebasnya. Adapun pengujian ini dapat dilakukan sebagai berikut :

\section{Uji Variabel secara Parsial (Uji t)}


Pengujian secara parsial digunakan untuk menguji apakah setiap koefisien regresi variabel bebas mempunyai pengaruh atau tidak terhadap variabel tidak bebas. Uji t dapat diperoleh dengan rumus, Rangkuti (2010) :

Dimana:

B = Koefisien Regresi

$\mathrm{Sb}=$ Standar Error

Kaidah pengujian signifikansi :

thitung $=b s b$

- Jika t hitung > t tabel, maka berpengaruh signifikan

- thitung $<\mathrm{t}$ tabel, maka tidak berpengaruh signifikan.

Mencari nilai $t$ tabel dengan menggunakan tabel $t$ dengan taraf signifikan $\alpha=0,05$.

\section{Pengujian asumsi klasik}

Pengujian terhadap asumsi klasik yaitu asumsi yang mendasari pelaksanaan regresi linier berganda supaya hasilnya dapat diandalkan, maka perlu menguji mengenai gejala multikolenieritas, heteroskedastisitas dan autokorelasi.

\section{Uji normalitas}

Uji normalitas bertujuan untuk menguji apakah dalam model regresi, variabel pengganggu atau residual memiliki distribusi normal. Seperti diketahui bahwa uji $\mathrm{t}$ dan $\mathrm{F}$ mengasumsikan bahwa nilai residual mengikuti distribusi normal. Kalau asumsi ini dilarang maka uji statistik menjadi tidak valid untuk jumlah sample kecil. Ada dua cara untuk mendeteksi apakah residual berdistribusi normal atau tidak yaitu dengan analisis grafik dan uji statistik, Ghozali (2010).

\section{Uji multikolenieritas}

Uji multikolonieritas bertujuan untuk menguji apakah model regresi ditemukan adanya korelasi antar variabel bebas (independen). Model regresi yang baik seharusnya tidak terjadi korelasi di antara variabel independen. Jika variabel independen saling berkorelasi, maka variabel-variabel ini tidak ortogonal. Variabel ortogonal adalah variabel independen yang nilai korelasi antar sesame variabel independen sama dengan nol, Ghozali (2010).

\section{Uji heteroskedastisitas}

Uji Heteroskedastisitas digunakan untuk melihat apakah ada korelasi yang kuat antara variabel penggangu dengan variabel independent. Heteroskedastisitas merupakan suatu gejala, dimana variabel pengganggu (variabel) pengaruhnya sangat berbeda atau mempunyai varian yang tidak sama antara observasi terhadap yang satu dengan lainnya, jika terjadi akan menyebabkan tidak efisien baik dalam sampel besar maupun sampel kecil, Algifari (2009).

\section{Uji autokorelasi}

Menurut Maholtra (2009), autokorelasi merupakan korelasi antara anggota sampel yang diurutkan berdasarkan sampel. Untuk mengadopsi adanya suatu model regresi dilakukan melalui uji Durbin Watson (Uji Dw). Uji autokorelasi bertujuan menguji apakah dalam model regresi linier ada korelasi antara kesalahan pengganggu pada periode $t$ dengan kesalahan pengganggu pada periode $\mathrm{t}-1$ (sebelumnya). Jika terjadi korelasi, maka dinamakan ada problem autokorelasi.

Autokorelasi muncul karena observasi yang berurutan sepanjang waktu berkaitan satu sama lainnya. Hal ini sering ditemukan pada data runtut waktu (time series) karena "gangguan" pada seseorang individu/kelompok cenderung mempengaruhi "gangguan" pada individu/kelompok yang sama pada periode berikutnya. Pada data crossection (silang waktu), masalah autokorelasi relatif jarang terjadi karena "gangguan" pada observasi yang berbeda berasal dari individu. Kelompok yang berbeda. Model regresi 
yang baik adalah regresi yang bebas dari autokorelasi, Ghozali (2010).

Untuk memudahkan penulis dalam melakukan perhitungan statistik maka digunakan bantuan program komputer SPSS (Statistical Package For Social Science) versi 19 untuk menganalisis dan menguji hipotesis tersebut.

\section{HASIL DAN PEMBAHASAN}

\section{Analisis kualitatif Uji validitas}

Pengujian validitas dalam penelitian ini dilakukan dengan menggunakan Pearson Correlation. Suyuthi dalam Sujianto (2009), menyatakan suatu pertanyaan itu dikatakan valid jika mempunyai nilai Pearson Correlation lebih dari 0,3 dengan tingkat signifikansinya berada di bawah 0,05.

Tabel 2. Uji validitas Dukungan

Organisasi $\left(\mathrm{X}_{1}\right)$

\begin{tabular}{llll}
\hline $\begin{array}{l}\text { Pernya } \\
\text { taan }\end{array}$ & Sig. & $\begin{array}{l}\text { Pearson } \\
\text { Correlation }\end{array}$ & Ket \\
$\mathrm{X}_{1.1}$ & 0.000 & 0.949 & Valid \\
$\mathrm{X}_{1.2}$ & 0.000 & 0.918 & Valid \\
$\mathrm{X}_{1.3}$ & 0.000 & 0.940 & Valid \\
$\mathrm{X}_{1.4}$ & 0.000 & 0.831 & Valid
\end{tabular}

Sumber : Data primer diolah, 2020

Tabel di atas adalah hasil uji validitas yang dilakukan dari setiap butir pertanyaan Dukungan Organisasi $\left(\mathrm{X}_{1}\right)$, dapat disimpulkan bahwa pernyataan kuesioner Dukungan Organisasi valid.

\begin{tabular}{llll}
\multicolumn{2}{c}{ Tabel 3.Uji } & \multicolumn{2}{c}{$\begin{array}{l}\text { validitas } \\
\text { Tugas }(\mathrm{X} 2)\end{array}$} \\
\hline $\begin{array}{l}\text { Pernya } \\
\text { taan }\end{array}$ & sig. & $\begin{array}{l}\text { pearson } \\
\text { correlation }\end{array}$ & Ket \\
\hline $\mathrm{X}_{2.1}$ & 0.000 & 0.871 & valid \\
$\mathrm{X}_{2 .} .2$ & 0.000 & 0.886 & valid \\
$\mathrm{X}_{2.3}$ & 0.000 & 0.820 & valid \\
$\mathrm{X}_{2.4}$ & 0.000 & 0.781 & valid
\end{tabular}

Sumber : Data Primer Diolah, 2020
Tabel 3 adalah hasil uji validitas yang dilakukan dari setiap butir pertanyaan Kejelasasn Tugas $\left(\mathrm{X}_{2}\right)$, dapat disimpulkan bahwa pernyataan kuesioner kejelasan Tugas valid.

Tabel 4. Uji validitas Lingkungan Kerja

$$
\left(\mathrm{X}_{3}\right)
$$

\begin{tabular}{llll}
\hline $\begin{array}{l}\text { Pernya } \\
\text { taan }\end{array}$ & sig. & $\begin{array}{l}\text { pearson } \\
\text { correlatio } \\
n\end{array}$ & ket \\
\hline X3.1 & 0.000 & 0.859 & valid \\
X3.2 & 0.000 & 0.908 & valid \\
X3.3 & 0.000 & 0.870 & valid \\
X3.4 & 0.000 & 0.731 & valid
\end{tabular}

Sumber: Data Primer Diolah, 2020

Tabel 4. adalah hasil uji validitas yang dilakukan dari setiap butir pertanyaan Lingkungan Kerja $\left(\mathrm{X}_{3}\right)$, dapat disimpulkan bahwa pernyataan kuesioner Lingkungan Kerja valid.

Tabel 5. Uji validitas Motivasi ( $\left.\mathrm{Y}_{1}\right)$

\begin{tabular}{llll}
\hline $\begin{array}{l}\text { Pernya } \\
\text { taan }\end{array}$ & sig. & $\begin{array}{l}\text { pearson } \\
\text { correlation }\end{array}$ \\
\hline Y1.1 & 0.000 & 0.906 & valid \\
Y1.2 & 0.000 & 0.883 & valid \\
Y1.3 & 0.000 & 0.779 & valid \\
YY1. & 0.000 & 0.827 & valid \\
4 & & &
\end{tabular}

Sumber : Data Primer Diolah, 2019.

Tabel 5. adalah hasil uji validitas yang dilakukan dari setiap butir pertanyaan Motivasi Kerja ( $\left.\mathrm{Y}_{1}\right)$, dapat disimpulkan bahwa pernyataan kuesioner Motivasi Kerja valid.

Tabel 6. Uji Validitas Profesional kerja $\left(\mathrm{Y}_{2}\right)$

\begin{tabular}{lll}
\hline $\begin{array}{l}\text { Pernya } \\
\text { taan }\end{array}$ & Sig. & $\begin{array}{l}\text { Pearson } \\
\text { Correlatio } \\
n\end{array}$ \\
& & \\
\hline
\end{tabular}




\begin{tabular}{cccc}
\hline Y2.1 & 0.000 & 0.925 & Valid \\
Y2.2 & 0.000 & 0.917 & Valid \\
Y2.3 & 0.000 & 0.952 & Valid \\
Y2.4 & 0.000 & 0.951 & Valid \\
Y2.5 & 0.000 & 0.906 & Valid \\
& & & \\
\hline
\end{tabular}

Sumber : Data Primer Diolah, 2020

Tabel 6 adalah hasil uji validitas yang dilakukan dari setiap butir pertanyaan Profesional Kerja $\left(\mathrm{Y}_{2}\right)$, dapat disimpulkan bahwa pernyataan kuesioner profesional kerja valid.

\section{Uji reliabilitas}

Menurut Nunally dalam Ghazali (2005), uji reliabilitas dilakukan dengan melihat nilai Cronbach's Alpha dengan kriteria sebagai berikut : Jika nilai Cronbach's Alpha $>0,60$ maka suatu instrumen dikatakan reliabel. Jika nilai Cronbach's Alpha $<0,60$ maka suatu instrumen dikatakan tidak reliabel. Pengujian dilakukan dengan per variabel menggunakan pernyataan yang terdapat didalam kuesioner. Dari pengujian yang dilakukan, diperoleh hasil sebagai berikut :

$\mathrm{T}$ Tabel 7. Uji reliabilita: Dukungan Organisasi $\left(\mathrm{X}_{1}\right)$

\begin{tabular}{lll}
\hline $\begin{array}{l}\text { Reliability } \\
\text { Statistics }\end{array}$ & & \\
\hline Cronbach's & Cronbach's & N of \\
Alpha & $\begin{array}{l}\text { Alpha Based } \\
\text { on }\end{array}$ & Items \\
& $\begin{array}{l}\text { Standardized } \\
\text { Items }\end{array}$ & \\
& & 4 \\
\hline 0.931 & & 4
\end{tabular}

Sumber : Data Primer Diolah, 2020

Tabel 7 adalah hasil Uji Reliabilitas yang dilakukan pada butir pertanyaan untuk variabel Dukungan Organisasi $\left(\mathrm{X}_{1}\right)$, dapat disimpulkan bahwa konstruk pernyataan pada variabel Dukungan Organisasi $\left(\mathrm{X}_{1}\right)$ adalah reliabel karena memiliki nilai Cronbach's Alpha $>0,60$.

Tabel 8. Uji reliabilitas Kejelasan Tugas kompensasi $\left(\mathrm{X}_{2}\right)$

\begin{tabular}{llc}
\hline Reliability Statistics \\
\hline $\begin{array}{l}\text { Cronbach's } \\
\text { Alpha }\end{array}$ & $\begin{array}{l}\text { Cronbach's N } \begin{array}{l}\text { Alpha Based on Items } \\
\text { Standardized }\end{array} \\
\text { Items }\end{array}$ \\
\hline 0.859 & & 4 \\
\hline
\end{tabular}

Sumber : Data Primer Diolah, 2020.

Tabel 8 adalah hasil Uji Reliabilitas yang dilakukan pada butir pertanyaan untuk variabel Kejelasan Uraian Tugas $\left(\mathrm{X}_{2}\right)$, dapat disimpulkan bahwa konstruk pernyataan pada variabel Kejelasan Uraian Tugas $\left(\mathrm{X}_{2}\right)$ adalah reliabel karena memiliki nilai Cronbach's Alpha $>0,60$.

Tabel 9. Uji reliabilitas Lingkungan $\operatorname{Kerja}\left(\mathrm{X}_{3}\right)$

\begin{tabular}{lc}
\hline Reliability Statistics \\
\hline Cronbach's A] & $\begin{array}{c}\text { N of } \\
\text { Items }\end{array}$ \\
\hline 0.863 & 4 \\
\hline
\end{tabular}

Sumber : Data Primer Diolah, 2020.

Tabel 9 adalah hasil Uji Reliabilitas yang dilakukan pada butir pertanyaan untuk variabel Lingkungan Kerja $\left(\mathrm{X}_{3}\right)$, dapat disimpulkan bahwa konstruk pernyataan pada variabel Lingkungan Kerja $\left(\mathrm{X}_{3}\right)$ adalah reliabel karena memiliki nilai Cronbach's Alpha $>0,60$.

Tabel 10. Uji reliabilitas Motivasi Kerja $\left(\mathrm{Y}_{1}\right)$

\begin{tabular}{lc}
\hline $\begin{array}{l}\text { Reliability } \\
\text { Statistics }\end{array}$ \\
$\begin{array}{l}\text { Cronbach' } \\
\text { s Alpha }\end{array}$ \\
\hline 0.866 & N of Items \\
\hline
\end{tabular}

Sumber: Data Primer Diolah, 2020.

Tabel 10 adalah hasil Uji Reliabilitas yang dilakukan pada butir pertanyaan untuk variabel Motivasi Kerja ( $\left.\mathrm{Y}_{1}\right)$, dapat disimpulkan bahwa konstruk pernyataan pada variabel Motivasi kerja $\left(\mathrm{Y}_{1}\right)$ adalah 
reliabel karena memiliki nilai Cronbach's Alpha $>0,60$.

Tabel 11. Uji reliabilitas profesional kerja $\left(\mathrm{Y}_{2}\right)$

\begin{tabular}{ll}
\hline $\begin{array}{l}\text { Reliability } \\
\text { Statistics }\end{array}$ & \\
\hline Cronbach & N of \\
S Alpha & Items \\
\hline 0.961 & 5 \\
\hline
\end{tabular}

Sumber : Data Primer Diolah, 2020.

Tabel 11 adalah hasil Uji Reliabilitas yang dilakukan pada butir pertanyaan untuk variabel profesional kerja $\left(\mathrm{Y}_{2}\right)$, dapat disimpulkan bahwa konstruk pernyataan pada variabel profesional kerja $\left(\mathrm{Y}_{2}\right)$ adalah reliabel karena memiliki nilai Cronbach's Alpha $>0,60$.

\section{Uji Asumsi Klasik}

Suatu hasil dari analisis akan dapat dijadikan sebagai dasar pengambilan kesimpulan jika telah memenuhi beberapa asumsi yang disebut dengan asumsi klasik. Asumsi klasik meliputi : tidak terjadi heteroskedastisitas, tidak terjadi autokorelasi, tidak terjadi multikolinearitas dan normalitas data. Hasil pengujian asumsi klasik atas data penelitian adalah sebagai berikut :

\section{Asumsi klasik sub-struktur 1}

\section{Uji Asumsi Normalitas Data}

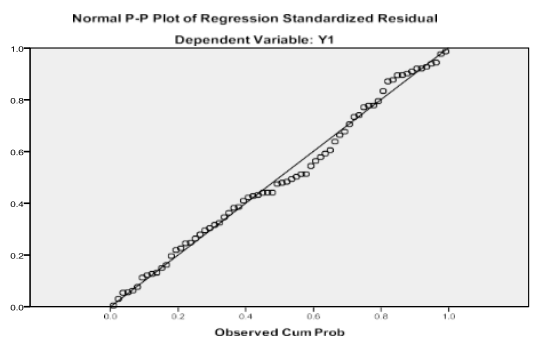

Gambar 1. Uji normalitas

Sumber data : Hasil data olah
Pada gambar grafik di atas, terlihat bahwa data-data dalam penelitian ini mendekati garis normal. Hal ini menunjukkan bahwa semua data yang digunakan dalam penelitian ini merupakan data yang berdistribusi normal.

\section{Uji multikolinieritas}

Tabel 12. Hasil uji multikolinieritas

\begin{tabular}{llll}
\hline $\begin{array}{l}\text { Varia } \\
\text { bel }\end{array}$ & $\begin{array}{l}\text { Toler } \\
\text { ance }\end{array}$ & VIF & Interprestasi \\
\hline X1 & 0.582 & 1.717 & Tidak terjadi \\
X2 & 0.590 & 1.695 & multikolinieritas \\
X3 & 0.954 & 1.048 & $\begin{array}{l}\text { Tidak terjadi } \\
\text { multikolinieritas Tidak } \\
\end{array}$ \\
& & & \begin{tabular}{l} 
terjadi multikolinieritas \\
\hline
\end{tabular} \\
\hline
\end{tabular}

Sumber : Data Primer Diolah, 2020.

Tabel diatas menunjukkan nilai tolerance yang lebih besar dari 0.1 atau nilai VIF (Variance Inflation Factor) kurang dari 10.Hal ini berarti bahwa varibel-variabel bebas dalam penelitian tidak terdapat gejala



multikolinearitas.

\section{Uji Heteroskedastisitas}




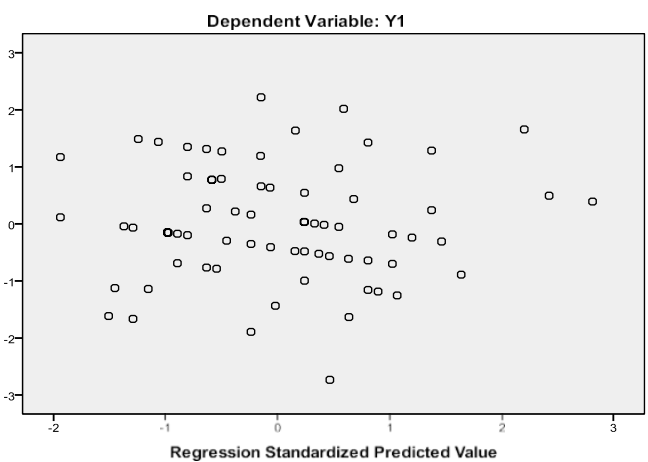

Gambar 2. Hasil uji heterokedastisitas

Sumber: Hasil olah data

Berdasarkan gambar diagram scatterplot di atas, terlihat bahwa data tidak membentuk suatu pola tertentu. Hal ini berarti model penelitian terbebas dari masalah heterokedastisitas.

\section{Uji Autokorelasi}

Tabel 13. Hasil Uji Autokorelasi

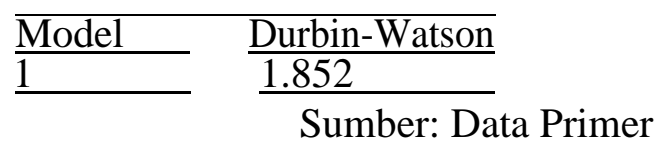

Diolah, 2020.

Dari hasil olah data diatas, ditemukan Durbin Watson test $=1.852$ dan DW berada diantara -2 dan +2 atau $-2<$ DW $<+2$ dapat disimpulkan bahwa data diatas tidak terjadi autokorelasi.

\section{Asumsi klasik sub-struktur 2.}

\section{Uji asumsi normalitas data}

Normal P-P Plot ot Regressıon Standardized Residual

Observed Cum Prob

Gambar 3. Uji normalitas

Sumber data : Hasil olah data

Pada gambar grafik di atas, terlihat bahwa data-data dalam penelitian ini mendekati garis normal. Hal ini menunjukkan bahwa semua data yang digunakan dalam penelitian ini merupakan data yang berdistribusi normal.

\section{Uji multikolinieritas}

Tabel 14. Hasil Uji Multikolinieritas

\begin{tabular}{llll}
\hline $\begin{array}{l}\text { Variabe } \\
1\end{array}$ & $\begin{array}{l}\text { Tolera } \\
\text { nce }\end{array}$ & VIF & Interprestasi \\
\hline $\mathrm{X} 1$ & .582 & 1.719 & Tidak terjadi \\
$\mathrm{X} 2$ & .584 & 1.711 & multikolinieritas \\
$\mathrm{X} 3$ & .893 & 1.119 & Tidak terjadi \\
Y1 & .929 & 1.076 & $\begin{array}{l}\text { multikolinieritas } \\
\text { Tidak terjadi }\end{array}$ \\
& & & \\
& & & $\begin{array}{l}\text { multikolinieritas } \\
\text { Tidak terjadi } \\
\text { multikolinieritas }\end{array}$ \\
& & &
\end{tabular}

Sumber: Data primer diolah, 2020.

Tabel diatas menunjukkan nilai tolerance yang lebih besar dari 0.1 atau nilai VIF (Variance Inflation Factor) kurang dari 10.Hal ini berarti bahwa varibel-variabel bebas dalam penelitian tidak terdapat gejala multikolinearitas.

\section{Uji heteroskedastisitas}

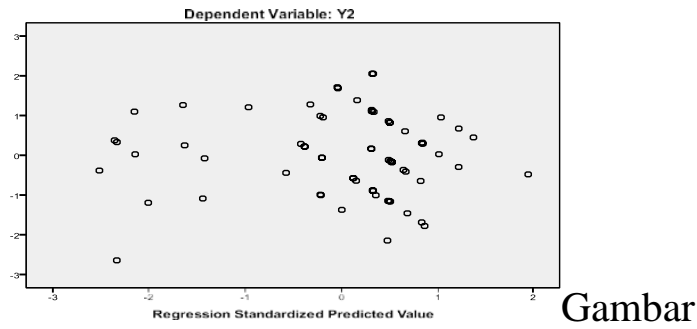

4. Hasil uji heterokedastisitas

Sumber: Hasil olah data

Berdasarkan gambar diagram scatterplot di atas, terlihat bahwa data tidak membentuk suatu pola tertentu. Hal ini berarti model penelitian terbebas dari masalah heterokedastisitas.

\section{Uji autokorelasi}

Tabel 15. Hasil uji autokorelasi

$\underline{\text { Model }} \quad \underline{\underline{\text { Durbin-Watson }}}$


Sumber: Data Primer Diolah, 2020.

Dari hasil olah data diatas, ditemukan Durbin watson test $=2.076$ dan DW berada diantara -2 dan +2 atau $-2<$ DW $<+2$ dapat disimpulkan bahwa data diatas tidak terjadi autokorelasi.

\section{Uji Analisis Jalur}

Dalam penentuan pengaruh variabel penelitian secara keseluruhan didapat nilai koefisien jalur I (substruktur pertama) dari penjumlahan seluruh variabel eksogen terhadap variabel endogen. Nilai koefisien jalur (berdasarkan estimate) variabel Dukungan Organisasi, Kejelasan Tugas dan Lingkungan Kerja terhadap Motivasi Kerja diolah dengan menggunakan software SPSS 19.0.

\begin{tabular}{|c|c|c|c|c|c|}
\hline & & beffici & $\mathbf{t s}^{\mathrm{a}}$ & & \\
\hline & $\begin{array}{l}\text { Uns } \\
\text { Coe }\end{array}$ & $\begin{array}{l}\text { andardi } \\
\text { ed } \\
\text { ficients }\end{array}$ & $\begin{array}{l}\text { Standardi } \\
\text { zed } \\
\text { Coefficien } \\
\text { ts }\end{array}$ & & \\
\hline Model & B & $\begin{array}{l}\text { Std. } \\
\text { Error }\end{array}$ & Beta & $\mathrm{t}$ & $\mathrm{Sig}$ \\
\hline 1 (Constant & $\begin{array}{r}.58 \\
2\end{array}$ & .855 & & .681 & $\begin{array}{r}.49 \\
8\end{array}$ \\
\hline $\begin{array}{l}\text { Dukunga } \\
\mathrm{n} \\
\text { Organisa } \\
\text { si }\end{array}$ & $\begin{array}{r}.25 \\
9\end{array}$ & .081 & .272 & $\begin{array}{r}3.21 \\
2\end{array}$ & $\begin{array}{r}.00 \\
2\end{array}$ \\
\hline $\begin{array}{l}\text { Kejelasan } \\
\text { Tugas }\end{array}$ & $\begin{array}{r}.47 \\
1\end{array}$ & .076 & .441 & $\begin{array}{r}6.19 \\
5\end{array}$ & $\begin{array}{r}.00 \\
0\end{array}$ \\
\hline $\begin{array}{l}\text { Lingkung } \\
\text { an Kerja }\end{array}$ & $\begin{array}{r}.26 \\
2\end{array}$ & .070 & .278 & $\begin{array}{r}3.72 \\
6\end{array}$ & $\begin{array}{r}.00 \\
0\end{array}$ \\
\hline
\end{tabular}

a. Dependent Variable: Motivasi Kerja

Pada fungsi 1 (sub-struktur-1), variabel eksogen $=\mathrm{X} 1, \mathrm{X} 2, \mathrm{X} 3$ dan variabel endogen Y1 dapat diketahui persamaan sebagai berikut: $\mathrm{Y} 1=0.272 \mathrm{X} 1-0.441 \mathrm{X} 2+0.278$ X3

Dalam penentuan pengaruh variabel penelitian secara keseluruhan didapat nilai koefisien jalur II (substruktur kedua) dari penjumlahan seluruh variabel eksogen terhadap variabel endogen. Nilai koefisien jalur (berdasarkan estimate) variabel Dukungan Organisasi , Kejelasan Uraian Tugas , lingkungan kerja dan Motivasi kerja terhadap profesional kerja diolah dengan menggunakan software SPSS 19.0.

\section{Coefficients $^{\mathrm{a}}$}

\begin{tabular}{|c|c|c|c|c|c|}
\hline & $\begin{array}{l}\text { Unst } \\
\text { Coef }\end{array}$ & $\begin{array}{l}\text { ndardi } \\
\text { ed } \\
\text { icients }\end{array}$ & $\begin{array}{c}\text { Standardiz } \\
\text { ed } \\
\text { Coefficien } \\
\text { ts }\end{array}$ & & \\
\hline Model & B & $\begin{array}{l}\text { Std. } \\
\text { Error }\end{array}$ & Beta & $\mathrm{t}$ & Sig \\
\hline 1 (Constant & $\begin{array}{r}.01 \\
3\end{array}$ & .755 & & .017 & $\begin{array}{r}.98 \\
7\end{array}$ \\
\hline $\begin{array}{l}\text { Dukunga } \\
\mathrm{n} \\
\text { Organisa } \\
\text { si }\end{array}$ & $\begin{array}{r}.37 \\
3\end{array}$ & .075 & .305 & $\begin{array}{r}4.97 \\
9\end{array}$ & $\begin{array}{r}.00 \\
0\end{array}$ \\
\hline $\begin{array}{l}\text { Kejelasan } \\
\text { Tugas }\end{array}$ & $\begin{array}{r}.28 \\
6\end{array}$ & .080 & .209 & $\begin{array}{r}3.59 \\
5\end{array}$ & $\begin{array}{r}.00 \\
1\end{array}$ \\
\hline $\begin{array}{l}\text { Lingkung } \\
\text { an Kerja }\end{array}$ & $\begin{array}{r}.15 \\
5\end{array}$ & .066 & .129 & $\begin{array}{r}2.34 \\
1\end{array}$ & $\begin{array}{r}.02 \\
1\end{array}$ \\
\hline Motivasi & $\begin{array}{r}.49 \\
8\end{array}$ & .092 & .389 & $\begin{array}{r}5.42 \\
8\end{array}$ & $\begin{array}{r}.00 \\
0\end{array}$ \\
\hline
\end{tabular}

Pada fungsi 2 (sub-struktur-2), variabel eksogen $=\mathrm{X} 1, \mathrm{X} 2 \mathrm{X} 3$ dan $\mathrm{Y} 1$ serta variabel endogen Y2 dapat diketahui persamaan sebagai berikut: $\quad \mathrm{Y} 2=0.305 \mathrm{X} 1+0.209$ $\mathrm{X} 2+0.129 \mathrm{X} 3-0.389 \mathrm{Y} 1$

\begin{tabular}{|c|c|c|c|c|c|c|}
\hline \multirow{2}{*}{$\begin{array}{l}\mathrm{N} \\
\mathrm{o}\end{array}$} & \multicolumn{2}{|c|}{$\begin{array}{l}\text { Pengaruh } \\
\text { langsung }\end{array}$} & \multicolumn{2}{|c|}{$\begin{array}{c}\text { Pengaruh } \\
\text { tidak langsung }\end{array}$} & \multicolumn{2}{|l|}{$\begin{array}{l}\text { Pengaruh } \\
\text { total }\end{array}$} \\
\hline & $\begin{array}{l}\text { Varia } \\
\text { bel }\end{array}$ & $\begin{array}{l}\text { Nil } \\
\text { ai }\end{array}$ & Variabel & Nilai & Variabel & $\begin{array}{l}\text { Nil } \\
\text { ai }\end{array}$ \\
\hline 1 & X1- & 0.2 & - & - & Direct + & 0.2 \\
\hline & Y1 & 72 & & & Indir & 72 \\
\hline 2 & $\mathrm{X}_{2}-$ & 0.4 & - & - & Direct + & 0.4 \\
\hline & Y1 & 41 & & & Indir & 41 \\
\hline 3 & X3- & 0.2 & - & - & Direct + & 0.2 \\
\hline & $\mathrm{Y}_{1}$ & 78 & & & Indirect & 78 \\
\hline 4 & X1- & 0.3 & Y1) $\mathrm{x}$ & - & Direct + & 0.3 \\
\hline & Y2 & 05 & (Y1 & $\begin{array}{l}0.10 \\
5\end{array}$ & Indi & 05 \\
\hline 5 & $\mathrm{X}_{2-}$ & 0.2 & $\left(\mathrm{X}_{2}-\mathrm{Y}_{1}\right) \mathrm{x}$ & 0.17 & Dir & 0.2 \\
\hline & Y2 & 09 & (Y1-Y2) & 1 & Indir & 09 \\
\hline 6 & X3- & 0.1 & $(\mathrm{X} 3-\mathrm{Y} 1) \mathrm{x}$ & - & Direct + & 0.1 \\
\hline & $\mathrm{Y}_{2}$ & 29 & $(\mathrm{Y}$ & $\begin{array}{l}0.10 \\
8\end{array}$ & Indirect & 29 \\
\hline 7 & $\begin{array}{l}\text { Y1- } \\
\text { Y2 }\end{array}$ & $\begin{array}{l}0.3 \\
89\end{array}$ & - & - & $\begin{array}{l}\text { Direct }+ \\
\text { Indirect }\end{array}$ & $\begin{array}{l}0.3 \\
89\end{array}$ \\
\hline
\end{tabular}


Berdasarkan tabel 5.15 dan tabel 5.16 maka diperoleh persamaan untuk sub struktur I dan sub struktur II yang selanjutnya akan diaplikasikan kedalam diagram analisis jalur sebagai berikut:

- Untuk persamaan substruktur pertama: $\mathrm{Y} 1=0.272 \mathrm{X} 1-0.441 \mathrm{X} 2+0.278$ $\mathrm{X} 3$

- Untuk persamaan substruktur kedua: $\mathrm{Y} 2=0.305 \mathrm{X} 1+0.209 \mathrm{X} 2+0.129$ $\mathrm{X} 3-0.389 \mathrm{Y} 1$

Berikut ini gambar model persamaan analisis dua jalur:

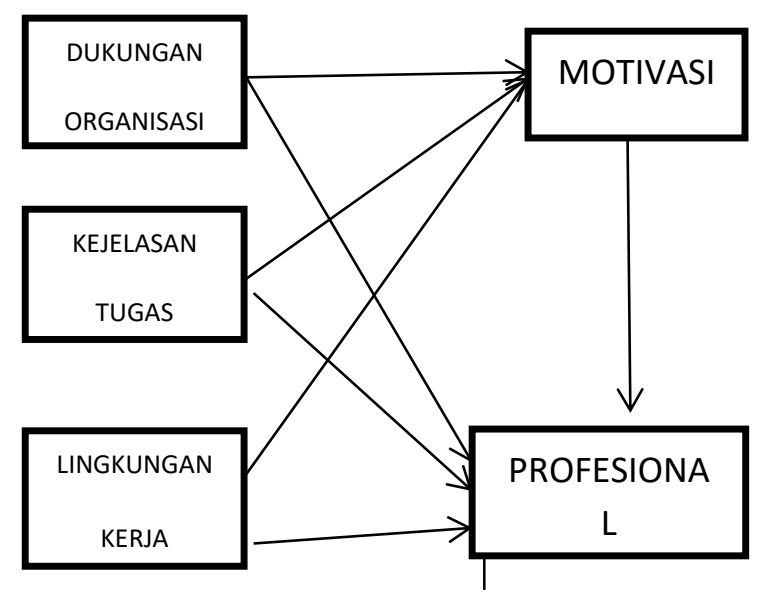

Gambar Model analisis dua jalur Sumber: Hasil olah data

Berdasarkan gambar tersebut maka diperoleh keterangan mengenai pengaruh langsung, pengaruh tidak langsung dan pengaruh total yang dapat dilihat pada tabel dibawah ini:

Tabel 18. Pengaruh langsung, pengaruh tidak langsung dan pengaruh total

Sumber: Tabel 4.15 dan Tabel 4.16.

Berdasarkan tabel diatas dapat diketahui pengaruh langsung, pengaruh tidak langsung dan pengaruh total masingmasing variabel eksogen yang terdiri dari lingkungan kerja, kompensasi dan komitmen organisasi terhadap variabel endogen yang terdiri dari Motivasi kerja dan profesional kerja dengan penjelasan sebagai berikut:

Pengaruh langsung Dukungan Organisasi , kejelasan tugas dan Lingkungan Kerja terhadap Motivasi kerja perawat di RSUD Jaraga Sasaneh Buntok

- Pengaruh langsung Dukungan Organisasi terhadap Motivasi Kerja sebesar 0,272

- Pengaruh langsung Kejelasan Uraian Tugas terhadap Motivasi Kerja sebesar 0,441

- Pengaruh langsung Lingkungan Kerja terhadap Motivasi kerja sebesar 0,278

- Pengaruh langsung Dukungan Organisasi terhadap profesional kerja sebesar 0,305

- Pengaruh langsung Kejelasan Tugas terhadap profesional kerja sebesar 0,209

- Pengaruh langsung Lingkungan kerja terhadap profesional kerja sebesar 0,129

- Pengaruh langsung Motivasi kerja terhadap profesional kerja sebesar 0,389

Pengaruh tidak langsung Dukungnan Organisasi , Kejelasan Tugas dan Lingkungan Kerja terhadap profesional kerja melalui Motivasi kerja perawat di RSUD Jaraga Sasameh Buntok.

- Pengaruh tidak langsung Dukungan Organisasi terhadap profesional kerja melalui Motivasi pegawai sebesar -0.105

- Pengaruh tidak langsung Kejelasan Uraian Tugas terhadap profesional kerja melalui motivasi pegawai sebesar 0.171

- Pengaruh tidak langsung Lingkungan Kerja terhadap profesional kerja melalui motivasi kerja pegawai sebesar -0.108

Koefisien determinasi (R2) mampu memberikan informasi mengenai variasi 
nilai variabel dependen yang dapat dijelaskan oleh model regresi yang digunakan.Apabila R2 mendekati angka satu berarti terdapat hubungan yang kuat. Nilai R2 yang diperoleh dijelaskan pada tabel berikut ini:

\begin{tabular}{ll|r|r|r}
\multicolumn{7}{c}{ Model Summary } \\
Model & $\mathrm{R}$ & $\begin{array}{c}\text { R } \\
\text { Square }\end{array}$ & $\begin{array}{c}\text { Adjusted } \\
\text { R Square }\end{array}$ & $\begin{array}{c}\text { Std. Error } \\
\text { of the } \\
\text { Estimate }\end{array}$ \\
\hline 1 & $.956^{\mathrm{a}}$ & .914 & .910 & 1.32898
\end{tabular}

a. Predictors: (Constant), Dukungan Organisasi,

Kejelasan Tugas, Lingkungan Kerja, dan

Profesional Kerja

Berdasarkan hasil data didapatkan nilai koefisien korelasi sebesar 0.266, nilai tersebut mempunyai arti bahwa tingkat hubungan variabel eksogen terhadap variabel endogen rendah karena berada dalam interval 0.200-0.399.

Nilai koefisien determinasi (R2) sebesar 0.071 artinya bahwa $7.10 \%$ variasi dari variabel Motivasi Kerja dapat dijelaskan oleh Dukungan Organisasi , Kejelasan Uraian Tugas dan lingkungan kerja, sedangkan $92.90 \%$ lainnya dijelaskan oleh variabel lain yang tidak masuk dalam variabel yang diteliti.

\begin{tabular}{|c|c|c|c|c|}
\hline \multicolumn{5}{|c|}{ Model Summary } \\
\hline Model & $\mathrm{R}$ & $\begin{array}{c}\mathrm{R} \\
\text { Square }\end{array}$ & $\begin{array}{c}\text { Adjusted } \\
\text { R } \\
\text { Square }\end{array}$ & $\begin{array}{c}\text { Std. } \\
\text { Error of } \\
\text { the } \\
\text { Estimate }\end{array}$ \\
\hline 1 & $.903^{\mathrm{a}}$ & .816 & .809 & 1.51043 \\
\hline
\end{tabular}

a. Predictors: (Constant), Dukungan Organisasi, Kejelasan Tugas, Lingkungan Kerja

Berdasarkan hasil data didapatkan nilai koefisien korelasi sebesar 0.844, nilai tersebut mempunyai arti bahwa tingkat hubungan variabel eksogen terhadap variabel endogen sangat kuat karena berada dalam interval 0.800-1.000.

Nilai koefisien determinasi (R2) sebesar 0.713 artinya bahwa $71.30 \%$ variasi dari variabel profesioanal kerja dapat dijelaskan oleh Motivasi Kerja , Dukungan Organisasi dan Kejelasan Tugas dan lingkungan kerja, sedangkan $28.70 \%$ lainnya dijelaskan oleh variabel lain yang tidak masuk dalam variabel yang diteliti.

\section{Uji F (uji simultan)}

Hasil pengujian F (Uji Simultan) atau uji secara bersama-sama sebagai berikut :

\section{Tabel Hasil Perhitungun Uji F} ANOVA ${ }^{a}$

\begin{tabular}{lr|r|r|r|r} 
Model & $\begin{array}{l}\text { Sum of } \\
\text { Squares }\end{array}$ & df & $\begin{array}{c}\text { Mean } \\
\text { Square }\end{array}$ & F & Sig. \\
\hline \begin{tabular}{lr|r|r|r} 
Regressio \\
$\mathrm{n}$
\end{tabular} & 927.735 & 3 & 309.24 & 135.55 & .000 \\
& & & 5 & 0 & $\mathrm{~b}$ \\
\hline Residual & 209.890 & 9 & 2.281 & & \\
& & 2 & & & \\
\hline Total & 1137.62 & 9 & & & \\
& 5 & 5 & & & \\
& & & & & \\
\hline
\end{tabular}

a. Dependent Variable: Profesional Kerja

b. Predictors: (Constant), Dukungan Organisasi, Kejelasan Tugas, Lingkungan Kerja

Tabel di atas menunjukkan bahwa secara keseluruhan nilai pada tabel ANOVA terlihat nilai signifikansi $0,181>5 \%$ untuk seluruh variabel, dengan demikian dapat diambil kesimpulan bahwa secara bersamasama Dukungan Organisasi ,

Kejelasan Uraian Tugas dan Lingkungan kerja tidak berpengaruh secara signifikan 


\section{CAdNAlents ${ }^{\mathrm{a}}$}

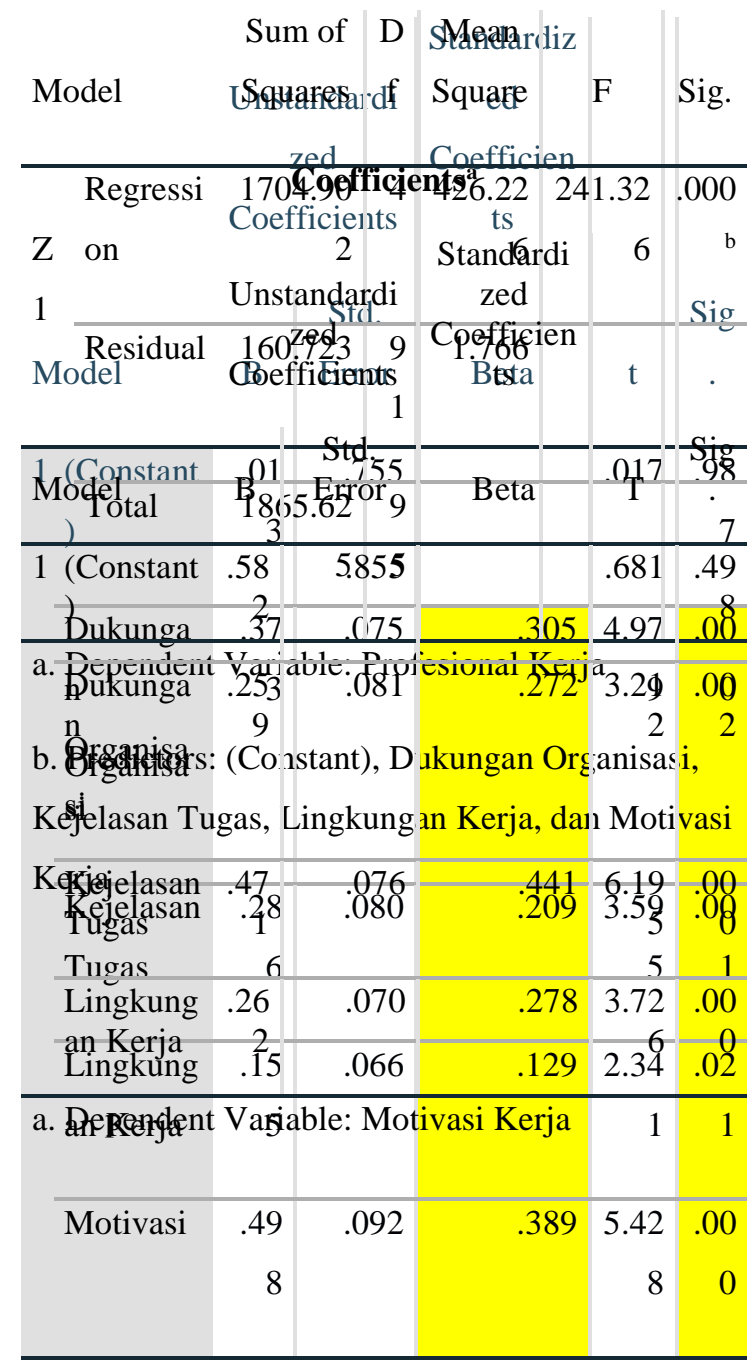

terhadap Motivasi Kerja kerja Perawat di RSUD Jaraga Sasameh Buntok.

Tabel di atas menunjukkan bahwa secara keseluruhan nilai pada tabel ANOVA terlihat nilai signifikansi $0,000<5 \%$ untuk seluruh variabel, dengan demikian dapat diambil kesimpulan bahwa secara bersamasama Dukungan Organisasi, Kejelasan uraian Tugas dan lingkungan kerja, serta Motivasi kerja berpengaruh secara signifikan terhadap profesional kerja perawat di RSUD Jaraga Sasameh Buntok.

\section{Uji t (Uji Parsial)}

Pengujian ini untuk mengetahui adanya pengaruh variabel eksogen $=\mathrm{X} 1, \mathrm{X} 2, \mathrm{X} 3$ terhadap variabel endogen $\mathrm{Y} 1$ dan mengetahui pengaruh variabel eksogen $=$ $\mathrm{X} 1, \mathrm{X} 2, \mathrm{X} 3$, Y1 terhadap variabel endogen Y2 hasil pengujian secara parsial sebagai berikut:

Tabel diatas dapat dijelaskan sebagai berikut:

- Pada level of significant 0.05 , diperoleh signifikansi untuk variabel Dukungan Organisasi, sebesar $0.002>5 \%$, Dengan demikian variabel Dukungan Organisasi terbukti secara statistik tidak berpengaruh signifikan terhadap variabel Motivasi kerja pegawai.

- Pada level of significant 0.05 , diperoleh signifikansi untuk variabel Kejelasan Uraian Tugas , sebesar $0.000>5 \%$, Dengan demikian variabel Kejelasan Uraian Tugas terbukti secara statistik tidak berpengaruh signifikan terhadap variabel Motivasi Kerja pegawai.

- Pada level of significant 0.05 , diperoleh signifikansi untuk variabel Lingkungan Kerja, sebesar $0.000<5 \%$, Dengan demikian variabel Lingkungan Kerja terbukti secara statistik berpengaruh signifikan terhadap variabel Motivasi kerja pegawai.

- Pada level of significant 0.05, diperoleh signifikansi untuk variabel Dukungan Organisasi, sebesar. $0.000<5 \%$, Dengan demikian variabel Dukungan Organisasi terbukti secara statistik berpengaruh signifikan terhadap variabel profesional kerja pegawai.

- Pada level of significant 0.05 , diperoleh signifikansi untuk variabel kejelasan Tugas , sebesar $0.001<5 \%$, Dengan 
demikian variabel Kejelasan Uraian Tugas terbukti secara statistik berpengaruh signifikan terhadap variabel profesional kerja pegawai.

- Pada level of significant 0.05 , diperoleh signifikansi untuk variabel Lingkungan Kerja , sebesar $0.021>5 \%$, Dengan demikian variabel Lingkungan kerja terbukti secara statistik tidak berpengaruh signifikan terhadap variabel profesional kerja pegawai.

- Pada level of significant 0.05 , diperoleh signifikansi untuk variabel Motivasi kerja, sebesar $0.000>5 \%$, Dengan demikian variabel Motivasi kerja terbukti secara statistik tidak berpengaruh signifikan terhadap variabel preofesional kerja pegawai.

\section{SIMPULAN}

Terkait dengan hubungan antara variabel pada model, berdasarkan hasil analisis yang telah dikemukakan pada bab sebelumnya dapat ditarik kesimpulan sebagai berikut:

Hasil penelitian menunjukkan berdasarkan persamaan substruktur -1 dan nilai uji $t$, dapat diketahui bahwa variabel Dukungan Organisasi terbukti berpengaruh positif akan tetapi tidak signifikan terhadap variabel Motivasi Kerja Hasil penelitian menunjukkan berdasarkan persamaan substruktur dan nilai uji t, dapat diketahui bahwa variabel kejelasan Tugas terbukti berpengaruh negatif dan tidak signifikan terhadap variabel Motivasi kerja.

Hasil penelitian menunjukkan berdasarkan persamaan substruktur dan nilai uji $t$, dapat diketahui bahwa variabel Lingkungan kerja terbukti berpengaruh positif dan signifikan terhadap variabel Motivasi kerja.
Hasil penelitian menunjukkan berdasarkan persamaan substruktur -2 dan nilai uji t, dapat diketahui bahwa variabel Motivasi terbukti berpengaruh positif dan signifikan terhadap variabel profesional kerja.

Hasil penelitian menunjukkan berdasarkan persamaan substruktur dan nilai uji $t$, dapat diketahui bahwa variabel Dukungan Organisasi terbukti berpengaruh positif dan signifikan terhadap variabel profesional kerja.

Hasil penelitian menunjukkan berdasarkan persamaan substruktur dan nilai uji $t$, dapat diketahui bahwa variabel Kejelasan Tugas terbukti berpengaruh positif akan tetapi tidak signifikan terhadap

variabel prestasi kerja.

Hasil penelitian menunjukkan berdasarkan persamaan substruktur dan nilai uji $t$, dapat diketahui bahwa variabel Motivasi Kerja terbukti berpengaruh negatif dan tidak signifikan terhadap variabel profesional kerja.

\section{DAFTAR PUSTAKA}

Akdon.2010. Aplikasi Statistika dan Metode Penelitian untuk Administrasi dan Manajemen. Dewi Ruchi. Bandung.

Algifari.2009. Analisis Regresi, Teori, Kasus \& Solusi.BPFEUGM.Yogyakarta. Alwi, Hasan. 2009. Kamus Besar Bahasa Indonesia. Balai Pustaka. Jakarta.

Amilin. Dewi, Rosita. 2010. Pengaruh Komitmen Organisasi terhadap Kepuasan Kerja Akuntan Publik dengan Role Stress Sebagai Variabel Moderating. Jurnal Volume 12 No. 1, Juni 2010 UIN Syarif Hidayatullah Jakarta 
Arep, Ishak dan Hendri Tanjung. 2009. Manajemen Sumber Daya Manusia. Universitas.Trisakti.

Jakarta.

As'ad. M. 2010. Psikologi Industri: Seri Sumber Daya Manusia. Yogjakarta: Liberty.

Brahmasari. Ida Ayu. 2009. Pengaruh Variabel Budaya Organisasi terhadap Komitmen Karyawan dan Kinerja Organisasi Kelompok Penerbitan Pers Jawa Pos. Disertasi Universitas Airlangga. Surabaya.

Davis. Keith dan Newstorm.John W. 2010. Organizational Behaviour: Human Behaviour at work. Mc- Graw Hill Companies. New York

Desiana, P.M \& Soetjipto B. W, 2009. Pengaruh Role Stressor dan Persepsi Dukungan Organisasi (Perceived Organizational Support) Terhadap Kepuasan Kerja dan Komitmen: Studi Kasus Asisten Dosen FEUI. Usahawan No. 05 Tahun XXXV.

Djarwanto dan Pengestu SUbagyo. 2010. Statistik Induktif. BPFEUGM.Yogyakarta.

Ghozali, Imam. 2010. Aplikasi Analisis Multivariat dengan Program SPSS. Badan Penerbit Universitas Diponegoro. Bandung.

Handoko. T. Hani. 2009. Manajemen Personalia dan Sumber Daya Manusia.Dasar dan Kunci Keberhasilan. Cetakan Keenam. H.Masanung Offset. Jakarta.
Hariandja.Marihot T.E. 2012. Manajemen Sumber Daya Manusia. Grasindo. Jakarta.

Haristryanto, Firman. 2012. Pengaruh Kompensasi Terhadap Prestasi Kerja Karyawan pada Perum Perumnas Regional VII Makassar.Jurusan Manajemen Fakultas Ekonomi dan Bisnis Universitas Hasanuddin Makassar.

Hartanto. Frans Mardi. 2009. Paradigma Baru Manajemen Indonesia: Menciptakan Nilai Bertumpu Pada Kebijakan dan Potensi Insani. Cetakan Pertama. PT Mizan Pustaka. Bandung.

Hasibuan.Malayu.S.P. 2010. Manajemen Sumber Daya Manusia. Edisi Revisi. PT.Bumi Aksara. Jakarta

Hatta, Muhammad. 2011. Tesis "Analisis Faktor-faktor yang Berpengaruh Terhadap Kualitas Pelayanan Kepada Masyarakat Melalui Kinerja Pegawai Badan Pelayanan Perijinan Terpadu (BPPT) Kabupaten Berau". Magister Manajemen. Universitas Mulawarman Samarinda. Karyawan (Studi Pada Perum Jasa Tirta I Malang Bagian Laboratorium Kualitas Air). Dalam Jurnal: Ekonomi dan Bisnis. Universitas Brawijaya. 